\title{
A CAUSALITY ANALYSIS OF THE RELATIONSHIPS BETWEEN GROSS FIXED CAPITAL FORMATION, ECONOMIC GROWTH AND EMPLOYMENT IN SOUTH AFRICA
}

\author{
Daniel Francois MEYER* \\ North West University, South Africa \\ Kaseem Abimbola SANUSI \\ North West University, South Africa and Obafemi Awolowo University, Nigeria
}

\begin{abstract}
In terms of macro-economic policy, gross fixed capital formation, which is the major component of domestic investment, is seen as an important process that could accelerate economic growth. This study re-examines the controversial issue of causality between domestic investment, employment and economic growth using South African data. The traditional assumption of causality running from investment to economic growth has remained inconclusive while empirical findings on the investment and employment growth nexus are also largely unsettled. The study makes use of quarterly data from 1995Q1 to 2016Q4 within the framework of the Johansen cointegration and Vector Error Correction Models (VECM). The empirical findings suggest that a long run relationship exists between domestic investment, employment and economic growth, with causality running from economic growth to investment and not vice versa. The results also demonstrate that investment has a positive long-run impact on employment. The empirical evidence further suggests bi-directional causality between employment and economic growth, while evidence of uni-directional causality, from investment to employment, is also found. The major implication of the study is that although there is bi-directional causality between economic growth and employment, economic growth does not translate to increased employment in the long run confirming "jobless growth". Investment is found to be a positive driver of employment in the South African economy in the long-run. The study concludes that, in order to stimulate employment, investment enhancing policies, such as low interest rates and a favourable economic environment should be put in place to accelerate growth. Measures to promote economic growth, such as improved infrastructural facilities and diversification of the economy, should be further engineered so as to encourage increased investment.
\end{abstract}

Corresponding author. Address: School of Economic Sciences, TRADE research unit, Faculty of Economic and Management Sciences, Hendrik van Eck Boulevard, Vanderbijlpark, North-West University, South Africa, E-mail: daniel.meyer@nwu.ac.za 
JEL Classification: E22; E24.

Keywords: Domestic investment, economic growth, employment, Granger causality, South Africa.

\section{Introduction}

Domestic investment, or gross fixed capital formation, has in terms of theory recognized as an essential component to facilitate economic growth and employment (Overseas Development Institute (ODI, 2016)). Keynes argued that new and additional investment increases the aggregate demand in the economy (Tobin, 1965). An increase in domestic investment occurs when existing firms make new investment or new domestic investors enter the market (Faulkner, Loewald \& Makrelov, 2013). Theoretically, an increase in investment is expected to provide more jobs or increase the employment level. Meanwhile, higher growth rate of the economy has also been agued to stimulate domestic investments. As a result, from theoretical point of view, there exists bi-directional causality between investment and economic growth. However, improvements in innovation, science and technology, which have resulted in manpower being displaced by machines and leading to a situation known as "jobless growth" may undermine the role of investment in accelerating the growth of an economy (Coombs \& Green, 1981; Hodge, 2009). Some of the functions previously performed by people have been computerised or mechanised, a process which allows certain types of work to be completed more efficiently and more cost effectively, enhancing productivity (Davis, 1991). In sum, this process may result in employment losses in the economy and consequently lead to jobless growth (Frey \& Osborne, 2015).

Empirical literature has established a robust positive relationship between investment and economic growth (Levine \& Renelt, 1992; Mankiw et al., 1992; De Long \& Summers, 1992). However, there are limited empirical studies that consider the impact of investment on employment creation in the literature. De Long and Summers (1992) assert that the positive association actually represents a causal link running from investment to economic growth. In this view, increased growth is triggered by higher investment rates or higher capital formation in the form of investment in equipment. However, Kuznet (1973) was of the opinion that there were cases where acceleration in growth had preceded increases in investment. By implication, he argued there could be cases where the causal link could run from economic growth to investment; not vice versa. Few empirical findings have supported this claim in the literature. Motivated by this claim, Summers and Heston (1991) investigated a set of 101 Organization for Economic Co-operation and Development (OECD) countries using averages of investment shares and economic growth over the post war period: they observed that an increase in the level of investment is preceded by steady and long term economic growth. Blomstrom et al. (1996) found that economic growth Granger-cause investment, but investment does not Granger-cause economic growth. Similar results are reported by Carroll and Weil (1994). This has led to an interrogation of the earliest theoretical position that investment Granger-causes long-run economic growth and not vice versa. This study revisits the relationship on the direction of causality between investment and 
economic growth on the one hand, and between investment and employment on the other. Also, most of the existing empirical studies have mainly focused on the nexus between foreign direct investments and economic growth. The study would be contributing to scarce empirical studies on the relationship between domestic investments, employments and economic growth. The remainder of the study is structured as follows: Section 2 reviews relevant theories and literature while Section 3 presents the econometric methods and procedures. Section 4 provides the empirical results; the last section, 5 , concludes the study.

\section{Literature Review}

The central role of domestic investment as one of the engines of growth is contained in several economic growth theories (Keller \& Yeaple, 2009). Reig (2013) mentions the classical political economy of the nineteenth century, the Keynesian view of growth (Harrod-Domar model), the neoclassical growth theory (Solow and Denison) and the endogenous growth theories. This theoretical position was examined in the light of several empirical studies. Bond et al. (2007) discover evidence for 94 non-OECD countries where a major share of investment in economic growth generates a higher level of output per worker, as well as a higher rate of growth in the long term. On the contrary, there is not much empirical evidence in favour of investment leading to economic growth. In this study, Bond et al. (2007) mention that a large number of recent studies have found that investment does not Granger cause economic growth, such as Jones (1995) and Blomstrom et al. (1996). These approaches address the issue of investment by means of different emphases but all agree that investment is important in explaining the growth pattern of the economy (Mordecki \& Ramírez, 2008).

Other authors have emphasised that causality does not move from investment to growth, because in most cases, investment levels depend on the preceding business cycles (Mordecki \& Ramírez, 2008; McKinnon, 2010). Antelo and Valverde (1994), on the other hand, investigated private investment in Bolivia. They argued in view of the Keynesian theory that investment affects economic growth positively and depends on the expected rate of return of capital. Antelo and Valverde (1994) added that according to the neoclassical theory, investment depends on economic growth and interest rates. However, in developing countries where financial markets are less developed, the level of interest rate is not a significant determinant of investment. Attanasio et al. (2000) found that investment Granger causes growth; another related study by Bond et al. (2004), also provides evidence that investment Granger causes economic growth. They investigated 94 countries; their empirical findings also suggest that a major share of investment in GDP generates a higher level of output per worker, as well as a higher rate of growth in the long term. Meanwhile, Cheung et al. (2012), found heterogeneity in the relationship between investment and growth. They examined the case of 188 rich and poor countries. Their empirical findings largely suggest a negative association between investment and economic growth. This, they argued, is particularly true for developing countries. Similarly, Ibarra and Moreno-Brid (2004), who studied the relationship between economic growth, investment and foreign direct investment (FDI) in Mexico, find that investment depends crucially on economic growth and real wages. 
Mordecki and Ramírez (2014) investigated the relationship between domestic investment, economic growth and employment in Uruguay, using a VECM framework. Their findings propose a long-term relationship between economic growth, investment and employment. The Granger test results suggest that economic growth precedes investment and employment, while investment also precedes employment. Podrecca and Carmeci (2001) examined the causal relationship between investment and economic growth using panel data in European countries. They established that causality between investment and growth is bi-directional. The above findings are confirmed by Bekhet and Othman (2011).

Kanu and Ozurumba (2014) researched the impact of capital formation on the economic growth of Nigeria by means of multiple regression analysis and a VAR model. They found that variables such as total exports, domestic investment and lagged values of economic growth had positive relationships with economic growth on the long run. No significant relationships were established on the short run between the variables. This result is supported by earlier studies in Nigeria. For instance, Ugochukwu and Chinyere (2013) and Bakare (2011) argued that capital formation is positively and significantly related to economic growth in Nigeria. Similarly, Shuaib and Dania (2015) and Adegboyga and Odusanga (2014) also confirmed that investment has a significant positive impact on economic growth.

Mohsen and Maysam (2013) investigated the causal relationship between gross domestic investment and economic growth for the Middle East and North African countries. They employed a panel unit root tests and panel cointegration analysis from 1970 to 2010 . Their empirical findings suggest strong causality from economic growth to investment in these countries. However, they confirmed that investment has no significant effects on economic growth in the short- and long-run. Consequently, their findings support the line of argument in the literature that economic growth is the driver of investment. In another dimension, Rajni (2013) argued that a bi-directional causality exists between gross domestic capital formation and export growth. His empirical findings also support the evidence of uni-directional causality from capital formation to changes in exports.

locovoiu (2012) examined the relationship between the net capital investment and employment in Romania. He concluded that net capital formation positively and significantly affects employment. Within the framework of a Structural Vector Analysis, Karim, Karim and Zaidi (2012) empirically researched the dynamic relationship between economic growth, fixed investment and household consumption in Malaysia. Their findings confirm the evidence that fixed investment significantly affects economic growth. They, however, argued that fixed investments significantly affect economic growth only in the short run. Neanywa and Makhenyane (2016) studied the impact of investment on the economic growth of South Africa. They employed the Johansen co-integration econometric method and a vector error correction model (VECM). Their empirical results revealed that gross fixed capital formation has a positive relationship with economic growth in the short as well as in the long-run. They also found evidence of bi-directional causality between gross capital formation and economic growth. Kumo (2012) examined investment in infrastructure and economic growth in South Africa by means of a Granger causality analysis; the empirical findings revealed the evidence of bi-directional causality between investment in infrastructure investment and economic growth. 
In conclusion, there is no conclusive evidence from the literature review of the direction of causality between investment, economic growth and employment. The South African case analysis presents evidence from 1995 to 2016 and allows a modern perspective from a developing country's point of view.

\section{Methods and Econometric Procedures}

To carry out this study, a vector autoregressive (VAR) model with error correction mechanism (VECM) was estimated. The variables used in the study include: economic growth with GDP as the measurement, gross fixed capital formation for domestic investment, number of people employed as employment and exports. Export was included because of its significant theoretical relationship with the remaining variables and as such being mostly used in the literature. All series were converted to logarithms. The variables with abbreviations are listed as the log of real GDP (LRGDP), log of investment (LINV), log of employment (LEMPLOY) and log for exports (LEXP). All the data for the series are extracted from the South African Reserve Bank (SARB) data base. The series were taken quarterly; modelling was from the first quarter of 1995 to the fourth quarter of 2016. In order to analyse the integration degree of the series to be modelled, the augmented unit root testing was performed using the Dickey-Fuller (ADF) and Phillips and Perron (PP) tests for both levels and first differences of all the variables. Both the ADF and PP unit root tests utilise the various specifications of the following regression model (Levin, Lin, \& Chu, 2002):

$$
\Delta x_{t}=\propto+\beta x_{t-1}+\lambda t+\sum_{s=1}^{n} \gamma_{s} \Delta x_{t-s}+\varepsilon_{t}
$$

Where $x_{t}$ is the variable of interest, $\varepsilon_{t}$ is the disturbance term and $t$ is a time trend. Assuming that each of the variables contains a unit root in levels, but not in the first differences, one can proceed to determine the number of cointegrating vectors among the variables in question. Johansen (1991) suggested a method to test for cointegration by considering the following $p$-variable VAR model:

$$
X_{t}=\mu+\sum_{i=1}^{k} \theta_{i} X_{t-i}+\eta_{t}
$$

Where $X_{t}$ is $(p \times 1)$ vector of the variables in question, which is $(4 \times 1)$ vector. $\eta_{t}$ is the disturbance term assumed to be a normally and independently distributed Gaussian process with zero mean and variance $\Omega$. Although these variables are individually non-stationary, if there are linear combinations of these variables that are stationary, then they form a meaningful and stable long run relationship. Thus, exploiting the notion that they are cointegrated, one may re-parameterise equation (2) to obtain the following vector error correction representation (VECM):

$$
\Delta X_{t}=\mu+\sum_{i=1}^{k-1} \Gamma_{i} \Delta X_{t-i}+\Pi X_{t-k}+\eta_{t}
$$

The symbols included in equation (3) represents the following: the $\Gamma \mathrm{s}$ are parameters; and $\Pi$ represents the parameter matrix which rank defines the long-run relationships between the various variables included in the model. Johansen (1992) formulated test statistics to determine the $r$ based on the maximum likelihood estimation method, firstly the trace test and secondly the maximum eigenvalue test. 
The causal relationship between investment and economic growth on one hand and between investment and employment on the other hand, were examined with the help of the Granger-causality procedure based on VECM. This procedure is particularly attractive over the standard VAR because it permits temporary causality to emerge from the sum of the lagged coefficients of the explanatory differenced variable and the coefficient of the error correction term. In addition, the VECM allows causality to emerge, even if the coefficients of lagged differences of the explanatory variable are not jointly significant (Anoruo \& Ahmad, 2001).

\section{Empirical Findings and Discussion}

\subsection{Unit root tests}

Using equation (1), the ADF and PP unit root tests were estimated. Table 1 presents the results of the time series properties of the variables with both trend and intercept being significant. All the variables are non-stationary in levels $I(0)$ but stationary in first difference I(1) at 5 percent significant levels.

Table 1: Unit Root Results

\begin{tabular}{|l|l|r|r|r|}
\hline Variable & \multicolumn{2}{|l|}{ PDF test } & \multicolumn{2}{l|}{} \\
\hline & T-stat & P-value & T-stat & P-value \\
\hline LRGDP & -1.4724 & 0.5428 & -1.3726 & 0.5921 \\
\hline LEMPLOY & -0.4683 & 0.8912 & -0.4587 & 0.8931 \\
\hline LINV & -0.9619 & 0.7635 & -1.2073 & 0.6683 \\
\hline LEXP & -1.6491 & 0.4534 & -1.4086 & 0.5745 \\
\hline$\Delta$ LRGDP & -4.6708 & $0.0002^{*}$ & -4.5917 & $0.0003^{*}$ \\
\hline$\Delta$ LEMPLOY & -4.6766 & $0.0002^{*}$ & -7.4850 & $0.0001^{*}$ \\
\hline$\Delta$ LINV & -5.2081 & $0.0001^{*}$ & -5.2081 & $0.0001^{*}$ \\
\hline$\Delta$ LEXP & -13.1699 & $0.0001^{*}$ & -13.8226 & $0.0001^{*}$ \\
\hline
\end{tabular}

Note: ${ }^{*}$ implies rejection of the null hypothesis at the $1 \%$ level.

\subsection{Long-run analysis}

Having determined the stationarity of time series, the Johansen cointegration test for long-run relationships is performed to test for any linear combinations of the variables that have a common stochastic trend. The Johansen test is quite sensitive to the lag length selected; consequently, a lag selection test was conducted to determine the optimal lag length. A lag length of 2 was selected because this is supported by all the lag selection criteria. In a multivariate system, consisting of economic growth, employment, investment and export, the maximum number of cointegrating vectors is 3 , so that the null hypothesis is that there is no co-integrating vector and the alternative is that there is at least one co-integrating vector. The cointegration result is presented in Table 2. The null hypothesis of no co-integration (i.e. $r=0$ ) is rejected at the 5 percent significance level in all the cases. However, the alternative hypothesis that there are at most 3 co-integrating vectors $(r \leq 3)$ could not be rejected for all the cases. The fact that the variables are co-integrated suggests that there is a long-run equilibrium relationship between the variables in the time series as well as the existence of causality in at least one direction. 
Table 2: Johansen Cointegration Results

\begin{tabular}{|l|l|l|l|l|l|l|l|}
\hline \multicolumn{9}{|l|}{ Trace Test } & \multicolumn{5}{l|}{ Max Eigen Test } \\
\hline $\mathbf{H}_{\mathbf{0}}$ & $\mathbf{H}_{\mathbf{1}}$ & Trace stat & $\mathbf{P}$-value & $\mathbf{H}_{\mathbf{0}}$ & $\mathbf{H}_{\mathbf{1}}$ & Max Eigen stat & P-value \\
\hline $\mathrm{r}=0$ & $\mathrm{r} \geq 0$ & $64.9647^{*}$ & $0.0040^{*}$ & $\mathrm{r}=0$ & $\mathrm{r}>0$ & $36.8905^{*}$ & $0.0035^{*}$ \\
\hline $\mathrm{r} \leq 1$ & $\mathrm{r} \geq 1$ & 28.0740 & 0.2380 & $\mathrm{r} \leq 1$ & $\mathrm{r}=1$ & 14.2595 & 0.4385 \\
\hline $\mathrm{r} \leq 2$ & $\mathrm{r} \geq 2$ & 13.8146 & 0.3024 & $\mathrm{r} \leq 2$ & $\mathrm{r}=2$ & 10.5980 & 0.2829 \\
\hline $\mathrm{r} \leq 3$ & $\mathrm{r} \geq 3$ & 3.2159 & 0.5412 & $\mathrm{r} \leq 3$ & $\mathrm{r}=3$ & 3.2159 & 0.5412 \\
\hline
\end{tabular}

Note: Both Maximum-Eigen test and Trace test show one cointegrating equation at the $5 \%$ significance level.

Equations (4) and (5) present the results of the long-run relationship between the variables at 5 percent significant levels. From equation (4), the empirical results show that there is a positive, long-run relationship between employment, investments and export, while economic growth is found to have a negative long run impact on employment. This confirms the hypothesis of jobless growth in the long run in South Africa, and the unemployment rate remaining unacceptably high. Equation (5) indicates a positive long-run relationship between economic growth, investments and export. This positive long-run relationship between economic growth, investments and export is consistent with Kanu and Ozurumba (2014) as well as Mordecki and Ramírez (2014), Ugochukwu and Chinyere (2013), Bakare (2011) and Neanywa and Makhenyane (2016), amongst others. This, however, is in contrast to a number of other empirical studies which either could not establish a long-run relationship between investment and economic growth or established a negative long-run relationship as found by Mohsen and Maysam (2013), Podrecca and Carmeci (2001) as well as Cheung et al. (2012) and Attanasio et al. (2000). The observed negative relationship between growth and employment could be associated with inefficient use of fixed available factors of production and inadequate technological advancement.

LEMPLOY $=7.07-0.486$ LRGDP +0.27635 LINV + 0.9443LEXP

LRGDP $=14.53+0.567$ LINV -2.053 LEMPLOY + 0.193LEXP

\subsection{Causality tests}

Given the results of the co-integration tests, the next step is the estimation of the VECM of equation (3) to determine the direction of causality between employment, investment, economic growth and export. The results of the causality tests from the estimates of the VECM are reported in Table 3. 
Table 3: VEC Granger Causality

\begin{tabular}{|c|c|c|c|c|c|}
\hline \multirow{2}{*}{$\begin{array}{l}\text { Dependent } \\
\text { Variables }\end{array}$} & \multicolumn{5}{|c|}{ Independent Variables } \\
\hline & D(LRGDP) & D(LINV) & D(LEMPLOY) & D(LEXP) & $\begin{array}{l}\text { All Variables } \\
\text { Combined }\end{array}$ \\
\hline $\mathrm{D}(\mathrm{LRGDP})$ & - & $\begin{array}{l}5.5582 \\
\left(0.0621^{*}\right)\end{array}$ & $\begin{array}{l}3.9625 \\
(0.1379)\end{array}$ & $\begin{array}{l}2.8635 \\
(0.2389)\end{array}$ & $\begin{array}{l}11.1118 \\
\left(0.0850^{*}\right)\end{array}$ \\
\hline $\mathrm{D}(\mathrm{LINV})$ & $\begin{array}{l}11.7779 \\
\left(0.0028^{* * *}\right)\end{array}$ & - & $\begin{array}{c}0.5322 \\
(0.7663)\end{array}$ & $\begin{array}{l}0.1084 \\
(0.9472)\end{array}$ & $\begin{array}{l}18.4106 \\
\left(0.005^{* * *}\right)\end{array}$ \\
\hline D(LEMPLOY) & $\begin{array}{c}10.2534 \\
\left(0.0059^{\star * *}\right)\end{array}$ & $\begin{array}{l}1.0556 \\
(0.5899)\end{array}$ & - & $\begin{array}{l}6.2844 \\
\left(0.043^{* *}\right)\end{array}$ & $\begin{array}{l}22.2411 \\
\left(0.0011^{* * *}\right)\end{array}$ \\
\hline $\mathrm{D}($ LEXP) & $\begin{array}{l}15.5976 \\
\left(0.0004^{\star * \star}\right)\end{array}$ & $\begin{array}{c}2.6107 \\
{[0.2711]}\end{array}$ & $\begin{array}{l}3.8057 \\
(0.1491)\end{array}$ & - & $\begin{array}{l}28.9284 \\
\left(0.0001^{* * *}\right)\end{array}$ \\
\hline
\end{tabular}

Note: ${ }^{* *}$ implies rejection of the null hypothesis at the $1 \%$ level, ${ }^{* *}$ at the $5 \%$ level and ${ }^{*}$ at $10 \%$ level while the $p$-values are represented in parentheses ().

In the analysis of Table 3, a significance threshold at the $5 \%$ level was selected. As may be observed from Table 3, a unidirectional causality exists between GDP and investment, with causality running from GDP to investment and not the other way round (only at the $10 \%$ significance level), in South Africa. This position supports other studies in the literature that have argued that investment does not Granger cause growth (Mordecki \& Ramírez, 2014; Antelo \& Valverde, 1994). In addition, there is uni-directional causality running from real GDP to employment, not vice versa, while GDP is also found to drive export in South Africa. Lastly, it was found that changes in exports cause changes in employment. These findings confirm the previous empirical positions, such as Rajni (2013), Kanu and Ozurumba (2014) and Neanywa and Makhenyane (2016), among others.

To check the robustness of the results, the standard pairwise Granger causality test was also conducted. As recorded in Table 4, GDP causes investment but not vice versa, indicating that economic growth drives investment in South Africa. There exists a bi-directional causality between GDP and employment in South Africa, as well as between investment and employment. Furthermore it was found that GDP causes export and export causes employment. This empirical evidence affirms the earlier position and other studies, such as Mordecki and Ramírez (2014), Rajni (2013) and Adegboyga and Odusanga (2014).

\section{Table 4: Pairwise Granger Causality Test}

\begin{tabular}{|c|c|}
\hline The Null Hypothesis & P-values \\
\hline LEMPLOY does not Granger Cause LRGDP & $0.0586^{\star}$ \\
\hline LRGDP does not Granger Cause LEMPLOY & $0.0003^{* * *}$ \\
\hline LINV does not Granger Cause LRGDP & 0.3513 \\
\hline LRGDP does not Granger Cause LINV & $0.0006^{* * *}$ \\
\hline LEXP does not Granger Cause LRGDP & 0.2014 \\
\hline LRGDP does not Granger Cause LEXP & $5 . \mathrm{E}-07^{* * *}$ \\
\hline LINV does not Granger Cause LEMPLOY & $0.0157^{\star \star}$ \\
\hline LEMPLOY does not Granger Cause LINV & $0.0816^{*}$ \\
\hline LEXP does not Granger Cause LEMPLOY & $0.0201^{* *}$ \\
\hline LEMPLOY does not Granger Cause LEXP & 0.2092 \\
\hline LEXP does not Granger Cause LINV & 0.1812 \\
\hline LINV does not Granger Cause LEXP & $0.0058^{* * *}$ \\
\hline
\end{tabular}

Note: ${ }^{* *}$ implies rejection of the null hypothesis at the $1 \%$ level, ${ }^{* *}$ at the $5 \%$ level and ${ }^{*}$ at $10 \%$ level. 
The significance of the coefficient of real GDP from the VECM estimation in Table 5 is that real GDP adjusts in the short-term to the long-run relationship deviations, while the decision criteria for the other variables regarding the coefficients and t-values, suggests that they do not adjust in the short-run to the long-run relationship deviations.

Table 5: VECM estimation

\begin{tabular}{|c|c|c|c|c|}
\hline Error correction & D(LRGDP) & D(LINV) & D(LEMPLOY) & D(LEXP) \\
\hline $\begin{array}{l}\text { Cointegration } \\
\text { equation } 1\end{array}$ & $\begin{array}{l}-0.0153 \\
(0.0044) \\
{[-3.5118]}\end{array}$ & $\begin{array}{l}0.0197 \\
(0.0165) \\
{[1.1952]}\end{array}$ & \begin{tabular}{|l}
0.0154 \\
$(0.0061)$ \\
{$[2.5157]$}
\end{tabular} & $\begin{array}{l}0.0716 \\
(0.0350) \\
{[2.0452]}\end{array}$ \\
\hline D(LRGDP(-1)) & $\begin{array}{l}-0.4612 \\
(0.1233) \\
{[3.7398]}\end{array}$ & $\begin{array}{l}0.7743 \\
(0.4673) \\
{[1.6567]}\end{array}$ & $\begin{array}{l}0.3254 \\
(0.1734) \\
{[1.8767]}\end{array}$ & $\begin{array}{l}3.3022 \\
(0.9896) \\
{[3.3367]}\end{array}$ \\
\hline $\mathrm{D}(\mathrm{LRGDP}(-2))$ & $\begin{array}{l}-0.1669 \\
(0.1309) \\
{[1.2751]}\end{array}$ & $\begin{array}{l}1.1223 \\
(0.4960) \\
{[2.2624]}\end{array}$ & $\begin{array}{l}0.3314 \\
(0.1840) \\
{[1.8010]}\end{array}$ & $\begin{array}{l}0.8942 \\
(1.0504) \\
{[0.8513]}\end{array}$ \\
\hline $\mathrm{D}(\mathrm{LINV}(-1))$ & $\begin{array}{l}-0.01338 \\
(0.0304) \\
{[-0.4392]}\end{array}$ & $\begin{array}{l}0.3712 \\
(0.1154) \\
{[3.2148]}\end{array}$ & $\begin{array}{l}-0.0036 \\
(0.04285) \\
{[-0.0854]}\end{array}$ & $\begin{array}{l}0.3010 \\
(0.2445) \\
{[1.231]} \\
\end{array}$ \\
\hline $\mathrm{D}(\mathrm{LINV}(-2))$ & $\begin{array}{l}-0.0579 \\
(0.0294) \\
{[-1.9646]}\end{array}$ & $\begin{array}{l}-0.1373 \\
(0.1117) \\
{[-1.2300]}\end{array}$ & $\begin{array}{l}0.0404 \\
(0.0414) \\
{[0.9768]}\end{array}$ & $\begin{array}{l}-0.3410 \\
(0.2365) \\
{[-1.4419]}\end{array}$ \\
\hline D(LEMPLOY(-1)) & $\begin{array}{l}0.1314 \\
(0.0828) \\
{[1.5868]}\end{array}$ & $\begin{array}{l}0.1520 \\
(0.3138) \\
{[0.4846]}\end{array}$ & $\begin{array}{l}0.0218 \\
(0.1164) \\
{[0.1876]}\end{array}$ & $\begin{array}{l}0.2762 \\
(0.6644) \\
{[0.4157]}\end{array}$ \\
\hline D(LEMPLOY(-2)) & $\begin{array}{l}-0.0200 \\
(0.0802) \\
{[1.2877]} \\
\end{array}$ & $\begin{array}{l}-0.1574 \\
(0.3042) \\
{[-0.5177]}\end{array}$ & $\begin{array}{l}0.0158 \\
(0.1128) \\
{[0.1406]} \\
\end{array}$ & $\begin{array}{l}-1.2110 \\
(0.6441) \\
{[-1.8800]}\end{array}$ \\
\hline $\mathrm{D}(\operatorname{LEXP}(-1))$ & $\begin{array}{l}-0.0200 \\
(0.0131) \\
{[-1.5201]} \\
\end{array}$ & $\begin{array}{l}-0.0162 \\
(0.0499) \\
{[-0.3259]} \\
\end{array}$ & \begin{tabular}{|l|}
0.0105 \\
$(0.0185)$ \\
{$[0.5673]$} \\
\end{tabular} & $\begin{array}{l}-0.4547 \\
(0.1057) \\
{[-4.3021]} \\
\end{array}$ \\
\hline $\mathrm{D}(\operatorname{LEXP}(-2))$ & $\begin{array}{l}-0.0166 \\
(0.01284) \\
{[-1.2990]}\end{array}$ & $\begin{array}{l}-0.0085 \\
(0.0486) \\
{[-0.1762]}\end{array}$ & $\begin{array}{l}-0.0360 \\
(0.0180) \\
{[-1.9979]}\end{array}$ & $\begin{array}{l}-0.2372 \\
(0.1030) \\
{[-2.3029]}\end{array}$ \\
\hline
\end{tabular}

\subsection{Stability tests}

The diagnostic tests are presented in Table 6. The results indicate an absence of serial correlation and heteroscedasticity. The null hypothesis of no serial correlation, and no heteroscedasticity, were accepted because of the insignificance of the probability values as they are greater than 5 percent. Also, the null hypothesis of normal distribution was accepted since the probability value is greater than 5 percent. 
Table 6: Diagnostic test results

\begin{tabular}{|l|l|l|l|}
\hline Item & Applied Test & P-Value & \multicolumn{1}{|c|}{ Decision } \\
\hline Serial Correlation & LM Test & 0.4214 & No serial correlation \\
\hline Normality & Jacque Bera & 0.1976 & Variables normally distributed \\
\hline Heteroscedasticity & $\begin{array}{l}\text { Breusch Pagan } \\
\text { Godfrey }\end{array}$ & 0.2699 & No heteroscedasticity \\
\hline
\end{tabular}

\section{Conclusion}

The relationship and the direction of causality between investment, growth and employment has been an important subject of investigation in economic literature. This is because investment is traditionally believed to play a pivotal role in the growth process and growth is assumed to play an important role in employment generation. Evidence from the literature demonstrates that empirical findings on the nature of the relationship between investment and economic growth are far from being settled, since they are still divergent, and that the employment growth nexus also remains inconclusive. There are empirical studies in favour of the theoretical position that investment precedes growth, while there are others that provide evidence in favour of the hypothesis that growth determines investment. Likewise, some empirical studies furnish evidence of the positive impact of economic growth on employment while others argue the opposite.

This study, motivated by lack of consensus in the literature on the direction of causality between investment, employment and economic growth, investigated the nature of the relationship between these variables in South Africa within the framework of the Vector Error Correction Model (VECM). The empirical results show that a long run relationship exists between the variables. The empirical findings also suggest evidence in favour of bi-directional causality between employment and economic growth, with economic growth impacting negatively on the employment in the long-run. Economic growth is also found to precede investment, rather than vice versa. The major conclusion derived from the study is that economic growth is an important driver of investment, employment and export in the long-run in the South African economic environment. The empirical findings also confirm the jobless growth hypothesis in the long-run. The study concludes that, in order to stimulate employment, investment enhancing policies such as low interest rates and a favourable economic environment should be put in place. Government should also vigorously pursue growth stimulating policies such as improved infrastructural facilities and diversification of the economy so as to spur the investment level in the economy. Future research will include a comparative panel analysis on developing countries, including the BRICS countries with regard to the relationship between investment, growth and employment.

\section{References}

Adegboyega, B., Odusanya I. (2014). Empirical analysis of trade openness, capital formation, FDI and economic growth: Nigeria experience. The International Journal of Social Science and Humanities, 1: 36-50.

Anoruo, E., Ahmad, Y. (2001). Causal relationship between domestic savings and economic growth: Evidence from seven African countries. African Development Review, 13(2): 238-249. 
Antelo, E., Valverde, F. (1994). Determinant of private investment in Bolivia. Unidad de Análisis de Políticas Sociales y Económicas, 8: 1-30.

Attanasio, O., Picci, L., Scorcu, A. (2000). Saving, Growth, and Investment: A Macroeconomics Analysis using a Panel of Countries. The Review of Economics and Statistics, 82(2): 182-211.

Bakare, A.S. (2011). A theoretical analysis of capital formation and growth in Nigeria. Far East Journal of Psychology and Business, 3(2): 11-24.

Bekhet, H.A., Othman, N.S. (2011). Causality analysis among electricity consumption, consumer expenditure, gross domestic product (GDP) and foreign direct investment (FDI): Case study of Malaysia. Journal of Economics and International Finance, 3(4): 228-235.

Blomstro, M., Lipsey, R., Zejan, M. (1996). Is fixed investment the key to economic growth? Quarterly Journal of Economics, 111: 269-276.

Bond, S., Lebeblicioglu, A., Schiantarelli, F. (2007). Capital accumulation and growth: A new look at the evidence. IZA Discussion, 1174. https://ideas.repec.org/a/jae/japmet/v25y2010i7p1073-1099.html

Carroll, C.D., Weil, D.N. (1994). Savings and growth: a reinterpretation. Carnegie Rochester Conference Series on Public Policy, 40: 133-192.

Cheung, Y.W., Dooley, M.P., Sushko, V. (2012). Investment and growth in rich and poor countries (No. w17788). National Bureau of Economic Research.

Coombs, R., Green, K. (1981). Microelectronics and the future of service employment. Service Industries Journal, 1(2): 4-21.

Davis, T.R. (1991). Information technology and white-collar productivity. The Executive, 5(1): 55-67.

De Long, J.B., Summers, L.H. (1992). Equipment investment and economic growth: How strong is the nexus? Brookings Papers on Economics Activity, 157-211.

Faulkner, D., Loewald, C., Makrelov, K. (2013). Achieving higher growth and employment: Policy options for South Africa. South African Reserve Bank Working Paper, 13(3): 1-35.

Frey, B.C., Osborne, M. (2015). Technology at work: The future of innovation and employment. Global Perspectives \& Solutions, 1-108.

Hodge, D. (2009). Growth, employment and unemployment in South Africa. South African Journal of Economics, 77(4): 488-504.

lacovoiu, V. B. (2012). Impact of Capital Investments on Unemployment in the Context of Economic Crisis. The Case of Romania. Economic Insights-Trends \& Challenges, 64(4).

Ibarra, D., Moreno-Brid, J.C. (2004). Private investment, foreign direct investment and economic growth. ECLAC, United Nations.

Johansen, S. (1991). Estimation and hypothesis testing of cointegration vectors in Gaussian Vector Autoregressive Models. Econometrica, 59(6): 1551-1580.

Jones, C. (1995). Time series tests of endogenous growth models. Quarterly Journal of Economics, 110(2): 495-525.

Kanu, S.I., Ozurumba, B.A. (2014). Capital Formation and Economic Growth in Nigeria. Global Journal of Human-Social Sciences, 4(4): 1-17.

Karim, Z.A., Karim, B.A., Zaidi, M.A.S. (2012). Fixed investment, household consumption, and economic growth: A structural vector error correction model (SVECM) study of Malaysia. International Journal of Business and Society, 13(1): 63-74. 
Keller, W., Yeaple, S. R. (2009). Multinational enterprises, international trade, and productivity growth: firm-level evidence from the United States. The Review of Economics and Statistics, 91(4): 821-831.

Kumo, W.L. (2012). Infrastructure investment and economic growth in South Africa: A granger causality analysis. African development Bank Group Working Paper Series, (160). https://www.afdb.org/fileadmin/uploads/afdb/Documents/Publications.pdf. (accessed January 15, 2018).

Kuznets, S. (1973). Modern economic growth: Rate, structure, and spread (Vol. 2). New Haven, US: Yale University Press.

Levin, A., Lin, C. F., Chu, C. S. J. (2002). Unit root tests in panel data: asymptotic and finite-sample properties. Journal of Econometrics, 108(1): 1-24.

Levine, R., Renelt, D. (1992) A sensitivity analysis of cross country growth regressions, American Economic Review, 82: 942- 963.

Mankiw, N.G., Romer, D., Weil, D. (1992) A contribution to the empirics of economic growth. Quarterly Journal of Economics, 107: 407- 437.

McKinnon, R. I. (2010). Money and Capital in Economic Development. Brookings Institution Press.

Mohsen, M., Maysam, M. (2013). The Causality between Capital Formation and Economic Growth in MENA Region. International Letters of Social and Humanistic Sciences, 8, 1-7 doi:10.18052/www.scipress.com/ILSHS.8.1

Mordecki, G., Ramírez, L. (2014). Investment, growth and employment: VECM for Uruguay. Serie Documentos de Trabajo/FCEA-IE; DT07/14.

Neanywa, T., Makhenyane, L. (2016). Can investment activities in the form of capital formation influence economic growth in South Africa? SAAPAM Limpopo Chapter 5th Annual Conference Proceedings, 1-10.

Overseas Development Institute. (2016). What are the links between power, economic growth and job creation. Development Impact Evaluation, 1-30.

Podrecca, E., Carmeci, G (2001). Fixed investment and economic growth: New results on causality. Applied Economics, 33: 177-182.

Rajni, P. (2013). Linkages between export, import and capital formation in India. International Research Journal of Social Sciences. 2(3): 16-19.

Reig, N. (2013). Effects of foreign direct investment on investment in Uruguay in a long run perspective (1960-2011). Department of Economics, Faculty of social sciences, Universidad de la República, 4: 1-20.

Summers, R., Heston, A. (1991). A new set of international comparisons of real product and price levels estimates for 130 countries, Quarterly Journal of Economics, 106: 327-368.

Solow, R.J. (1956). A contribution to the theory of economic growth, Quarterly Journal of Economics, 70: 65- 94.

Shuaib, I.M., Ndidi, N.D.E. (2015). Capital formation: Impact on the economic development of Nigeria 1960-2013. European Journal of Business, Economics and Accountancy, 3(3): 23-40.

Tobin, J. (1965). Money and economic growth. Econometrica: Journal of the Econometric Society, 671-684.

Ugochukwu, U.S., Chinyere, U.P. (2013). The impact of capital formation on the growth of Nigerian economy. Research Journal of Finance and Accounting, 4(9): 36-42. 